\title{
THE EFFECT OF HAMBURGER STRATEGY ON STUDENTS' READING COMPREHENSION OF RECOUNT TEXTS
}

\author{
Ismalianing Eviyuliwati, Cesar Abi Sarwan \\ Syarif Hidayatullah State Islamic University of Jakarta, Indonesia \\ (ismalianing.eviyuliwati@uinjkt.ac.id)
}

Received: $15^{\text {th }}$ March 2018; Revised: $25^{\text {th }}$ May 2018; Accepted: $28^{\text {th }}$ June 2018

\begin{abstract}
The study is aimed at finding whether or not the Hamburger Strategy is effective to use in teaching reading comprehension of recount texts at the eighth-grade students of a Junior High School level called MTs. Daarul Ma'arif in Jakarta, Indonesia. The samples of the study are 43 students who are divided into two groups, the experimental class (22 students) and the controlled class (21 students). The research method used is a quantitative method which employs a quasi-experimental design. The data collection is conducted through pretests and posttests. The validity and the reliability of the tests are measured by using ANATES. Furthermore, the collected data are analyzed using SPSS version 23 to find the $t$-value, i.e. to know whether there is a significant difference of the mean scores of posttests of the two groups. The finding shows that the mean score of the experimental class is 77.27 and that of the control class is 70.00. The $t$-value is 2.892 . In addition, the hypothesis testing shows that at the sig. 2-tailed, probability values $(p)$ is 0.006 , while alpha value $(a)$ is 0.05 . In other words, $p$ $<a$, which indicates that $\mathrm{H} \Theta$ is rejected and $\mathrm{Ha}$ is accepted. In conclusion, the Hamburger Strategy is effective to use in teaching reading comprehension of recount texts at the 8thgrade students of MTs. Daarul Ma'arif, Jakarta, Indonesia.
\end{abstract}

Key Words: hamburger strategy; reading comprehension; recount text

\section{ABSTRAK}

Penelitian ini bertujuan untuk membuktikan apakah Strategi Hamburger efektif bila dipakai untuk mengajar Membaca Teks Recount pada siswa kelas 8 MTs Daarul Ma'arif Jakarta, Indonesia. Sampel penelitian ini terdiri dari 41 siswa yang terbagi dalam dua kelompok, kelompok ekperimen (22 siswa) dan kelompok kontrol (21 siswa). Penelitian ini adalah peneliatian kuantitatif dengan menggunakan desain kuasi-eksperimental. Pengumpulan data dilakukan dengan memberikan pretes dan postes. Validitas dan realibilitas tesnya diuji dengan ANATES. Setelah data terkumpul, dilakukan Uji-t melalui SPSS 23 untuk mengetahui adakah perbedaan yang signifikan pada rerata nilai postes kedua kelompok. Hasil penelitiannya menunjukkan bahwa rerata nilai postes kelompok eksperimen adalah 77,27 , sedangkan kelompok kontrol mendapatkan rerata nilai postes sebesar 70,00. Nilai-t nya ditemukan 2,892. Sedangkan dalam uji hipotesa disebutkan nilai probabilitas $(p)=0,006$ dan nilai alpha $((a)=0.05$. Dengan kata lain nilai $p<$ nilai (a), yang artinya $\mathrm{H} \boldsymbol{\theta}$ ditolak dan Ha diterima. Kesimpulannya, Hamburger Strategi efektif digunakan dalam mengajar Membaca Teks Recount siswa MTs. Daarul Ma'arif Jakarta, Indonesia.

Kata Kunci: strategi hamburger; pemahaman membaca; teks recount

How to Cite: Eviyuliwati., I., Sarwan, C. A.(2018). The Effect of Hamburger Strategy on Students' Reading Comprehension of Recount Texts. IJEE (Indonesian Journal of English Education), 5(1), 49-60. doi:10.15408/ijee.v5i1.9880 


\section{INTRODUCTION}

Reading comprehension is a part of reading skills. Some experts define that comprehension is an active process. Harmer claims that "reading is an exercise dominated by the eyes and the brain. The eyes receive messages and the brain has to work out the significances of the messages" (1996, p. 190). It means, in order to comprehend a text, a reader needs to synchronize his or her eyes and brain to acquire and extract the information a reader gets in the text. It also requires a reader to connect the content schemata of reading that he or she has to the words the author has written.

However, the preliminary study done at a Junior High School in Jakarta, Indonesia called MTs. Daarul Ma'arif, there are some obstacles that affect students' reading comprehension. First, they lack of background knowledge about the topic of a text. It makes them hard to understand what the text talks about. Second, the teacher-centred or conventional technique in teaching English also affects the students' reading comprehension. It creates passive classroom activity because the teacher uses one-way communication to the students most of the class time.

Thus, the writers consider that there must be a way to overcome those obstacles in comprehending the text.
Hamburger Strategy (Karge, 2006, p. 319) emerges as the strategy selected by the writers. It is a kind of strategy that helps students to comprehend the text by creating an image of hamburger. The writers expect the Hamburger Strategy can get the students' attention easily to learn reading comprehension on recount text. It can also stimulate the students' mind and their curiosity so that their reading comprehension on recount text will increase.

In addition, some studies employing Hamburger Strategy in English classes in Indonesia had revealed positive results (Aridona, 2013; Suhendra, 2014). However, in those studies, the Hamburger Strategy is used in teaching writing, as it was originally introduced by the founder. As far as the writers' concern, there has not been a study investigating the effectiveness of Hamburger Strategy in teaching reading comprehension, let alone for Junior High School students.

For those reasons, the writers would like to conduct a research to prove the effectiveness of using Hamburger Strategy on students' reading comprehension of recount texts in 8th grade students of MTs. Daarul Ma'arif in Jakarta, Indonesia.

There are a lot of reading definitions. Daiek and Anter point out, "Reading is an active process that 
depends on both an author's ability to convey meaning using words and readers' ability to create meaning from them" (2004, p. 5). It means reading is an interaction between both an author and a reader employing written texts or passages as the medium. Without this medium, reading process cannot occur. On the other hand, Harmer claims that "reading is an exercise dominated by the eyes and the brain. The eyes receive messages and the brain has to work out the significances of the messages" (1996, p. 190). It means, in order to comprehend a text, a reader needs to synchronize his or her eyes and brain to acquire and extract the information a reader gets in the text. It also requires a reader to connect the content schemata of reading that he or she has to the words the author has written.

In addition, Blachowichz and Ogle argue that comprehension is a constructive process; good readers construct the meaning from what they read and integrate the information they get to what they have known (2008, pp. 27-28). It means readers need to comprehend the meaning of a text and relate their content schemata of reading in order to comprehend the text and get the required information in it.

Alderson describes the schemata as "interlocking mental structures which represent readers' knowledge" (2005, p.
33). It means, the schemata does not depend on the author, it depends on how good the readers' background knowledge towards the text. When readers read a text, their schemata influence how they recognize information as well as how they comprehend it. However, content schemata in reading are divided into background knowledge; knowledge which may or may not be relevant to the content of a text, and subject-matter knowledge; it is relevant to the content and topic of the text. That is why comprehension always follows the reading. It means there is no reading without comprehension.

Reading and text are two things that cannot be separated. Anderson and Anderson argue, " A text is made when words are adjoined to communicate a meaning" (2003, p. 2). There are two main categories of text: the first is literary. It is used to tell about human experiences in an imaginative way and its purpose is to amuse readers, such as narrative text, poems or dramas; the second is factual. It is used to present information and ideas and its social function is usually to inform, instruct, or persuade readers, like explanation text, discussion text, exposition text, etc. There are so many kinds of texts learned by students in junior high. 
However, in this research, the writers focus only on recount text. Recount text is a kind of text which retells events or experiences in the past. Anderson and Anderson define that recount text is a piece of text that retells past events, usually in the order in which they happened (1998, p. 48). Its purpose is usually either to inform or to entertain the readers.

There are three generic structures of recount text (2003, pp. 24-25):

1) Orientation: It introduces the participants, place and time in the first paragraph.

2) Event: It describes series of event that happened in the past.

3) Reorientation: It is optional. It explains personal comment of the writer to the story.

Besides, the grammatical features of recount text are as follows: it uses simple past tense, action verbs such as hit, jump, sit, etc., chronological connectors such as then, first, etc., and linking verb such as was, were, etc.

In this research, hamburger is not a food. It is one of the teaching strategies. Originally, Hamburger Strategy is used to write an essay. Karge claims it as one of the memory-triggering devices in mnemonics (2006, pp. 319-331). Mnemonics are techniques for aiding both the acquisition and retrieval of learned materials (Sprinthall \& Sprinthall, 1990, p.100). It helps students to remember and retrieve information by forming associations that do not exist naturally in the content.

In addition, Beare states that Hamburger Strategy is one of the writing strategies to write an essay by using a picture of hamburger (2015). In the strategy, we create a picture of hamburger which is divided into three main components: top buns -it states the introduction and topic statements, the fillings -it states the arguments that support the topic, and bottom buns -it states the conclusion or the authors' opinion about the experience, in order to strengthen the information and store it into students'memory.

In fact, memory is a complex concept. It has many parts and kinds of memory. Crow and Crow define memory as a power of conscious to recall something (1958, p. 301). Sprinthall and Sprinthall (1990, p. 289), divides memory into two kinds:

"When information from the environment first stores on a receptor (sense organ), there is an extremely brief moment to be held it in memory. This memory, also known as the sensory register, called iconic memory for visual items and echoic memory or acoustic memory for auditory items. An 
echoic memory lasts long enough to enable a person to piece together a series of sound whereas iconic memory begins to fade in a few milliseconds."

However, still according to Sprinthall and Sprinthall (1990, p. 291), generally, memory is divided into two main systems for storing the information: long-term memory and short-term memory.

1) Short-Term Memory (STM)

It can encode only about seven separate items and can hold them for only a limited time. Thus, if a person were verbally given a phone number, he or she needs to hold it in STM long enough to dial the number.

2) Long-Term Memory (LTM)

The information from STM can also be processed and consolidated into long-term-memory (LTM). It has the potential for holding the encoded information for a lifetime. However, not all the information from STM enters LTM. The key to LTM storage is being motivated enough to engage in a rehearsal of the items in STM.

In brief, Hamburger Strategy can be used as one of the memorytriggering devices by making use of a picture of hamburger in the students' mind to strengthen the students' memory, especially their long-term memory, in order to store the information they get from what they learnt or what they read.

In order to achieve well comprehension of the text, the teachers need to know the process of using Hamburger Strategy in reading instruction since they will teach the students how to use it independently. Originally, hamburger strategy is used to write an essay. In writing, Zwiers in Afridona (2013, p. 6) explains that the procedures of Hamburger Strategy in writing are:

a) The teacher passes out a copy of hamburger model of text to each student.

b) The teacher gives the students a text prompt, e.g. "why peanut M\&Ms are the best type of candy."

c) The teacher brainstorms the students about the topic.

d) The students will come up with three top reasons why they choose Peanut M\&Ms are the best candy. The three reasons will also be written on the top bun.

e) The students write supporting details for each reason.

f) Finally, the students write their conclusion on the bottom bun. The students can restate their ideas, 
mention major details, and draw some conclusions.

Based on Zwier's procedures, thus, the writers applied the Hamburger Strategy as follows:

a) The teacher passes out a copy of hamburger model and a recount text to the students to stimulate them.

b) The teacher explains to the students what Hamburger Strategy is.

c) The teacher discusses the three main components of a paragraph or a story: the orientation as the top bun, the events as the fillings, and the re-orientation as the bottom bun, including its grammatical and language features.

d) The teacher asks the students to read the text and try to imagine it as a hamburger.

e) The students will be asked to comprehend the topic of the text.

f) Ask the students to comprehend the events (supporting details) of a text and remember all the information in it.

g) Ask the students to draw a conclusion based on the reorientation part of the text by imagining it as the bottom bun of a hamburger.

$h$. To test the students whether they comprehend the text or they still remember the information they get, the teacher gives them a test.

In short, the first way in using Hamburger Strategy is preparing the lesson well and beginning with the explanation of the three main components of a paragraph. After that, reread the text by imagining a hamburger in order to store the important information of a text easily, including its generic structures. The last, try to draw a conclusion of what the text talks about and restates of all the generic structures and grammatical features of the text, including the important information of the text, by imagining a hamburger.

\section{METHOD}

The population of the study was the 8th-grade students of MTs. Daarul Ma'arif in Jakarta, Indonesia. They consisted of 3 classes, VIII A, VIII B, and VIII $C$ with 22, 21, and 25 students, respectively. Therefore, the total number of the students are 68 students. To take the sample for this study, the writers used purposive sampling because the process of selecting the sample for the study involved a 
consideration about the quality of the sample or their mean score which had to be similar before the treatment. After conducting a pre-test to the three classes, VIII A, B, and C, the writers found that VIII $A$ and VIII $B$ had relatively similar quality. Therefore, the writers chose VIII A as the experimental class and VIII B as the control class. Moreover, the homogeneity test was also conducted by the writers to test the similarity of the sample to the population from which it was taken. To do the homogeneity test, the writer used Levene Statistic Test from IBM SPSS Statistics 23 software. The result showed that the significance level or probability value (p) from both experimental and control classes was 0.890. It meant that the significance level or probability value $(p)$ of the data was higher than the degree of significance of the study, i.e. $\alpha=0.05$. It indicated that the samples were homogenous.

The writers used quantitative method and quasi-experimental design to conduct the study. The writers chose a quasi-experimental design because the writers did not have the possibility to sign individual students into groups randomly since it could disturb the classrooms learning. The writers taught two different classes employing two different teaching strategies in six contact hours. In the experimental class, the writers employed Hamburger Strategy. While, in the control class, the writers employed conventional teaching in which the class was taught mostly by using teacher presentation.

To collect the data, the writers used tests (a pretest and a posttest) as the instruments of the study. Both tests had been proved valid and reliable through ANATES. The validity values of pretest and post-test were 0.73 and 0.90 , respectively. In addition, the reliability values of pre-test and post-test were 0.84 and 0.95 , respectively.

Before the treatment, the writers administered a pre-test to both classes in order to check the extent of students' similarity, especially their comprehension in recount text reading. In the test, the students were asked to answer 20 questions related to different topics of the texts: My First Camping Experience, Trip to Parapat, Trip to Situ Cileunca, and At the Zoo. After the treatment, the writer administered a post-test to see the students' growing score. Similar to the pre-test, the posttest also in the form of multiple-choice test, but the writers used different topics: Trip to Surabaya, My Vacation in Lembah Hijau, Trip to the Zoo, and Grandpa's Birthday. Furthermore, the writers gave guided questions to facilitate the students to answer the questions. The writers also made a 
limitation for the students to answer the question, i.e. they had to answer the questions within one hour.

Finally, the technique of analyzing the data of the students' scores of pretest and post -test from both experimental and control classes were analyzed by using the formula of $t$-test, to test the following research hypotheses:

a) Alternative hypothesis (Ha): "The use of Hamburger strategy is effective in teaching reading comprehension of recount text."

b) Null hypothesis (H0): “The use of Hamburger strategy is not effective in teaching reading comprehension of recount text."

\section{FINDINGS AND DISCUSSION}

\section{Findings}

The pre-tests were administered to both the experimental and control classes to know the students' reading comprehension ability before they were given the treatment. The study showed that the mean score of pre-test of the experimental class was 47.73 from 22 students. Moreover, there were only 2 students who got the highest score (60); 2 students got the lowest score (30); and 7 students got (the most frequent score (50). Meanwhile, the mean score of pretest of control class was definitely higher: 52.62 from 21 students. Moreover, the highest score was 65; the lowest score was 35; and the most frequent score appeared was 55 . Without regarding which class is lower or higher and by finding out that 65 is the highest score of the pretest, it showed that the 8th-grade students of MTs. Daarul Ma'arif has not yet reached a good comprehension in reading recount texts, since the 8 thgrade Minimum Criteria of English Learning targeted by the English teachers in the school was 70 .

The next data analyzed by the writers were the scores found from the post-test in the experimental and control classes given after the treatment finished. Unlike the results of the pretest, the study showed that the mean score of the post-test of the experimental class was 77.27 from 22 students. The lowest score was 60 ; the highest was 90; the most frequent score appeared was 80 . On the other hand, the mean score of the post-test of control class was 70.00. The lowest score of the control class was 55, the highest score was 85 and the most frequent score appeared was 70 .

After collecting the data of pretests and posttests, the writers conducted the normality test to check whether or not the data in which it came from the samples were distributed normally. 
Based on the criteria of normality hypotheses, if the significance level or probability value $>$ the degree of significance $(\alpha=0.05)$, then the data were normally distributed. On the other hand, if the significance level or probability value $<$ the degree of significance $(a=0.05)$, then the data were not normally distributed. The result explained that the significance level or probability value (p) of pre-test scores in the experimental class was 0.077 and that in the control classes was 0.113. In addition, the significance level or probability value (p) of post-test scores in the experimental class was 0.103 and in the control class was 0.331 . Thus, the result of normality test proved that the significance level or the probability value (p) was higher than $(>)$ the degree of significance $(\alpha=0.05)$. It indicated that the data of pre-test and post-test of experimental and control classes were distributed normally.

The next step the writers conducted was the hypotheses testing to see whether or not there was a significant difference in the result of post-tests after the treatment was given. To do this, IBM SPSS Statistics 23 program was employed, with the significance value (a) $5 \%$ or 0.05 . The hypotheses to be tested were as follows.

1) If sig. 2 tailed (p) value $>$ alpha $(\mathrm{a}=0.05)$, then $\mathrm{HO}$ is accepted and $\mathrm{Ha}$ is rejected. In other words, there is not any significant difference between the mean score of post-test of experimental and control classes. It also indicates that Hamburger Strategy is not effective to teach reading comprehension of recount texts.

2) If sig. 2 tailed (p) value < alpha $(\mathrm{a}=0.05)$, then $\mathrm{HO}$ is rejected and $\mathrm{Ha}$ is accepted. In other words, there is a significant difference between the mean score of post-test of experimental and controlled classes. It also indicated that Hamburger Strategy is effective to teach reading comprehension of recount texts.

The SPSS calculation stated that the mean score of students in experimental class was 77.27 and the mean score of students in control class was 70.00. It showed that there was a significant difference in mean score of both classes. The difference mean of both classes was 7.27 points in which the mean score of the experimental class was higher than the mean score of the control class.

Concerning the hypotheses testing, the SPSS showed that the value of $t$ count was 2.892. The df (Degree of Freedom) was 41, taken from the total number of students, which was 43, minus (-) 2. Furthermore, sig. 2 tailed or (p) value was 0.006. while the a was 0.05. According to the statistical hypotheses, if the sig. 2 tailed values (p) 
was smaller than $a(p<a) ;(0.006<$ 0.05), it indicated that $\mathrm{HO}$ was rejected and Ha was accepted.

\section{Discussion}

There is something worth an attention from the research findings above. At first, before given a treatment, the experimental class students got the lower mean score compared to that of the control class. However, after given the Hamburger Strategy treatment, the students in the experimental class obtained better scores in the post-test compared to the control one. It could be seen from the mean scores of the pre-test and posttest of both classes.

The mean score of the pre-test in the experimental class was 47.73 , while the mean score of the pre-test in the control class was 52.62. However, the mean score of the post-test in the experimental class was 77.27, while the mean score of the post-test in the control class was lower, i.e. 70.00. Therefore, the mean score of post-test of the experimental class was higher than of control class. Therefore, there was increasing points of the mean score in the experimental class. The mean score of the experimental class increased 29.54 points; from 47.73 to 77.27 .

In analyzing the t-test, if $\mathrm{p}<\mathrm{a}$, it meant that $\mathrm{H} 0$ was rejected and $\mathrm{Ha}$ was accepted. Meanwhile, if $p>a$, it meant that $\mathrm{H} 0$ was accepted and $\mathrm{Ha}$ was rejected. The result showed that $p$ value was 0.006 and a was 0.05 . It meant that the significance level or probability value (p) was higher than the degree of significance ( $\alpha$ ). Thus, it indicated that $\mathrm{HO}$ was rejected and $\mathrm{Ha}$ was accepted. In other words, there was a significant difference between the mean score of the post-test of the experimental and control classes. It also indicated that Hamburger Strategy was effective to teach reading comprehension on recount text.

The writers believed that the picture of hamburger in the students' mind may improve their reading comprehension. It could be seen from the implementation of the strategy in the class; the students who had read or learnt recount text by using Hamburger Strategy had better comprehension, had better interest to read, and had better ability to recall the information in the text. It is in line with what Afridona (2013) stated that Hamburger Strategy could be one of the attractive strategies in which it made the students fun to learn reading comprehension on recount text. She also explained that Hamburger Strategy can stimulate the students' mind. The last, she argues that Hamburger Strategy demonstrates in fun way how the information of a text is related to each other. 
To sum up, Hamburger Strategy could be one of the attractive strategies in which it made the students fun to learn reading comprehension on recount text. It also stimulated the students' memory to comprehend and memorize a text and assisted them to store the information they got from a text into their long-term memory so the students did not forget easily the information they had obtained from the text.

\section{CONCLUSION}

Based on the findings of the study, the writers can draw a conclusion that the use of Hamburger Strategy in teaching reading comprehension on recount text in MTs. Daarul Ma'arif in Jakarta, Indonesia is effective. It helps the students to comprehend the recount texts and facilitates the students to recall the important information easily from their memory.

Therefore, Hamburger Strategy is applicable to teach any materials other than English reading texts. Whenever the teachers have a teaching material which consists of three classifications, they can use the picture of hamburger consisting of three layers (the top bun, the fillings, and the bottom bun) as an analogy to help the students strengthen their memories.

\section{REFERENCES}

Afridona, L. (2013). “Teaching writing hortatory exposition text by combining hamburger strategy and quick write strategy for senior highschool students", Journal for Research in English Education of PGRI Sumatra Barat.

Alderson, J. C.. (2005). Assessing reading. New York: Cambridge University Press.

Anderson, M. and Kathy A. (1998). Text types in English. Type 3. South Yarra, Vic : Macmillan Education Australia.

Anderson, M. and Kathy A. (1998). Text types in English. Type 1. South Yarra, Vic : Macmillan Education Australia.

Blachowicz, C. \& Donna, O. (2008). Reading comprehension: Strategies for independent learners. New York: Guilford Press.

Crow, L. D., \& Alice, C. (1958). Educational psychology. New York: American Book Company.

Daiek, D. \& Nancy, A. (2004). Critical reading for college and beyond. New York: McGraw-Hill.

Harmer, J. (1996). The practice of English language teaching. New York: Longman.

Karge, B.. (2006). Knowing what to teach: Using authentic assessment to improve classroom instruction. Reading and Writing Quarterly: 
Overcoming Learning Difficulties, vol. 14, pp. 319-331.

Suhendra, D. (2014). The effect of using paragraph hamburger strategy on students' writing ability in narrative paragraph of the first year at M.A. Darul Hikmah, Pekanbaru. Journal of English Department of Teachers Training and Education UIN Sultan Syarif Kasim Pekan Baru, Riau.
Sprinthall, N. A. \& Richard, C. S. (1990). Educational psychology: A developmental approach. Fifth Edition. New York: McGraw-Hill Publishing Company.http://esl.about.com/od/w ritingadvanced/a/How-To-Write-AHamburgerEssay.htm. Retrieved on December 3, 2017 at 11:23 a.m. 